\title{
Tailor-Made Detection of Individual Phosphorylated and Non-Phosphorylated EPIYA-Motifs of Helicobacter pylori Oncoprotein CagA
}

\author{
Suneesh Kumar Pachathundikandi, Andrés Julián Gutiérrez-Escobar and Nicole Tegtmeyer * \\ Department of Biology, Division of Microbiology, Friedrich Alexander University Erlangen-Nuremberg, \\ Staudtstraße 5, D-91058 Erlangen, Germany \\ * Correspondence: Nicole.Tegtmeyer@fau.de
}

Received: 25 May 2019; Accepted: 8 August 2019; Published: 13 August 2019

\begin{abstract}
The gastric pathogen and carcinogen Helicobacter pylori (H. pylori) encodes a type IV secretion system for translocation of the effector protein CagA into host cells. Injected CagA becomes tyrosine-phosphorylated at the five amino acid residue Glutamate-ProlineIsoleucine-Tyrosine-Alanine (EPIYA)-sequence motifs. These phosphorylated EPIYA-sites represent recognition motifs for binding of multiple host factors, which then manipulate signaling pathways to trigger gastric disease. Thus, efficient detection of single phosphorylated EPIYA-motifs in CagA is required. Detection of phospho-CagA is primarily performed using commercial pan-phosphotyrosine antibodies. However, those antibodies were originally generated to recognize many phosphotyrosines in various mammalian proteins and are not optimized for use in bacteria. To address this important limitation, we synthesized 11-mer phospho- and non-phospho-peptides from EPIYA-motifs A, B, and $\mathrm{C}$, and produced three phospho-specific and three non-phospho-specific rabbit polyclonal CagA antibodies. These antibodies specifically recognized the corresponding phosphorylated and non-phosphorylated EPIYA-motifs, while the EPIYA-C antibodies also recognized the related East-Asian EPIYA-D motif. Otherwise, no cross-reactivity of the antibodies among EPIYAs was observed. Western blotting demonstrated that each EPIYA-motif can be predominantly phosphorylated during $H$. pylori infection. This represents the first complete set of phospho-specific antibodies for an effector protein in bacteria, providing useful tools to gather information for the categorization of CagA phosphorylation, cancer signaling, and gastric disease progression.
\end{abstract}

Keywords: CagA; cagPAI; dotblot; EPIYA motifs; Helicobacter pylori; signaling; type IV secretion; Abl and Src tyrosine kinases

\section{Introduction}

The Gram-negative pathogen Helicobacter pylori (H. pylori) represents one of the most prevalent persistent bacterial infections in humans, affecting about half of the world population. The pathogen is associated with various gastric diseases, such as peptic ulceration, and represents the main risk factor for the development of gastric cancer [1-4]. A major disease-associated virulence factor is its type IV secretion system (T4SS) encoded by the cytotoxin-associated genes (cag) pathogenicity island (cagPAI). The cagPAI is present in the chromosome of highly virulent $H$. pylori strains but absent in less virulent isolates. This T4SS represents a syringe-like pilus device positioned in the bacterial membrane, and pilus formation is induced by contact with the host target cell $[5,6]$. The only known effector protein delivered by the cagT4SS to date is CagA [7-9]. CagA is about 125-145 kDa in size and shares no homology with any other protein in sequence databases. Remarkably, CagA seems to mimic a host protein [10] that hijacks the tyrosine phosphorylation machinery of the host 
cell [11]. Upon injection by the T4SS, CagA was shown to undergo tyrosine phosphorylation by Src $[12,13]$ and Abl tyrosine kinases [14-16]. Subsequently, phosphorylated CagA (CagA $\left.{ }^{\mathrm{PY}}\right)$ can bind a selection of cellular interaction partners with Src homology 2 (SH2) domains to manipulate host cell signaling. Currently, about 25 cellular binding partners have been identified that can interact with CagA in a phosphorylation-dependent or phosphorylation-independent manner, manipulating signal transduction pathways involved in cytoskeletal rearrangements, cell proliferation, cell motility, cell death, and inflammation to trigger gastric disease, including gastric cancer [17]. Due to these functions, CagA has been called the first bacterial oncoprotein that acts in mammalian cells [2].

The phosphorylation sites in CagA were identified by site-directed mutagenesis as the so-called EPIYA (Glu-Pro-Ile-Tyr-Ala)-motifs [13,18-20]. In H. pylori isolates from North America, Europe, Australia, and some Asian states (e.g., India and Malaysia), three different EPIYA-motifs have been classified as EPIYA-A, $-\mathrm{B}$, and $-\mathrm{C}$, depending on the neighboring sequence $[2,7,21,22]$. In isolates originating from East Asia (e.g., China, Korea and Japan), the EPIYA-C can be replaced by a related EPIYA-D site. Notable variability in the number and configuration of the EPIYA-sites has been observed in CagA proteins worldwide [2,16,21-33]. The importance of CagA phosphorylation for the bacteria is unknown; however, production of $\mathrm{CagA}^{\mathrm{PY}}$ is required for the characteristic, so-called "scattering" or "elongation" phenotype, observed for H. pylori-infected cultured gastric epithelial cells, such as AGS (gastric adenocarcinoma) cells $[13,18,34,35]$. It was proposed that this phenotype has a key effect on $H$. pylori pathogenesis because it may impact various processes, such as wound healing, invasive growth, or metastasis of cancer cells, as well as immune responses in vivo [36-38].

Observations that CagA undergoes phosphorylation at tyrosine residues upon delivery into host cells have been mainly monitored by Western blotting and with commercial pan-phosphotyrosine antibodies [34,39-42]. These antibodies were developed to recognize multiple phosphotyrosine residues in mammalian cells, but were not specifically raised against bacterial proteins. Our recent studies identified six of those pan-phosphotyrosine antibodies, most notably PY-20, PY-99, and PY-100, recognizing both host cell proteins and phospho-CagA [43,44]. Using synthetic phosphoand non-phospho-peptides derived from each CagA EPIYA-motif, we have shown that a total of 9-11 amino acids containing the phospho-tyrosine residue in the EPIYA-motifs are necessary and sufficient for specific detection by these commercial antibodies, but the work revealed vast variability in sequence recognition $[43,44]$. In Western-type CagAs, three of the above antibodies recognized peptides of phosphorylated EPIYA-motifs A, B, and C equally well in vitro, whereas preferential binding to phosphorylated motif $\mathrm{A}$, and motifs $\mathrm{A}$ and $\mathrm{C}$, was found with two and one other antibodies, respectively $[43,44]$. However, systematic studies as to whether specific CagA EPIYA-sites can be detected by these antibodies during infection with H. pylori are not yet available, and based on the mentioned cross-reactivity might produce ambiguous results. Thus, the generation of phospho-specific antibodies for single EPIYA-motifs is urgently required. In the past, the generation of three respective rabbit antibodies was reported, which were produced against the peptide-based antigens RSVSPEPIpYATIDDL (EPIYA-motif C) [45], VGLSASPEPIpYAT (EPIYA-motif C) [5], and PEEPIPYTQVAK (EPIYA-motif B) [46]. However, these antibodies were not characterized in detail and a full set of phospho-specific EPIYA antibodies is not yet available. Here, we report the successful production of phospho-specific and non-phospho-specific polyclonal CagA antibodies raised against Western-type EPIYA-motifs A, B, and C, respectively, using 11-mer peptides as antigens. We confirmed the specificity of each antibody by Western blotting and demonstrate that the set of EPIYA-C antibodies also recognized the closely related EPIYA-D site. Subsequently, we performed infection experiments with Western- and East Asian-type H. pylori to study the patterns of CagA ${ }^{\mathrm{PY}}$ following delivery into host cells. These data demonstrate for the first time that each of the CagA EPIYA-motifs can be phosphorylated upon infection. Our results are, therefore, highly valuable for detailed analysis of CagA phosphorylation events during infection and for determining their importance in signaling and gastric disease development by H. pylori. 


\section{Results}

\subsection{Phylogenetic Analysis of H. pylori CagA Carrying EPIYA-Motifs A, B, C and D}

Currently, various major H. pylori populations have been described in tight relation with humans in Africa, Asia, Europe, and Sahul [47]. Many of the CagA proteins from these isolates contain the three EPIYA-sites A, B, and C/D. As a first step, the phylogeny of CagA-ABC/D types from 5 continents was investigated. The obtained tree separated protein sequences into two clusters: $A B D$ and $A B C$ (Figure 1). The ABD cluster is divided into Clades I and II, which are composed exclusively of hpEAsia strains. The ABC cluster is further divided into Clade III, which is composed of hpEurope strains, Clade IV, which contains strains from hpAsia2, Clade V, which is formed by hpEurope strains, Clade VI, which is composed of Latin-American strains closely related to the hpEurope population, and Clade VII, which contains the hpAfrica1 strains. The alignment shown in Figure 2 illustrates that CagA is characterized by a highly conserved set of amino acids located before and after each of the individual EPIYA-motifs A, B, and C/D (Figure 2; numbers 1 and 2 at the top of the aligned EPIYA-C/D block).

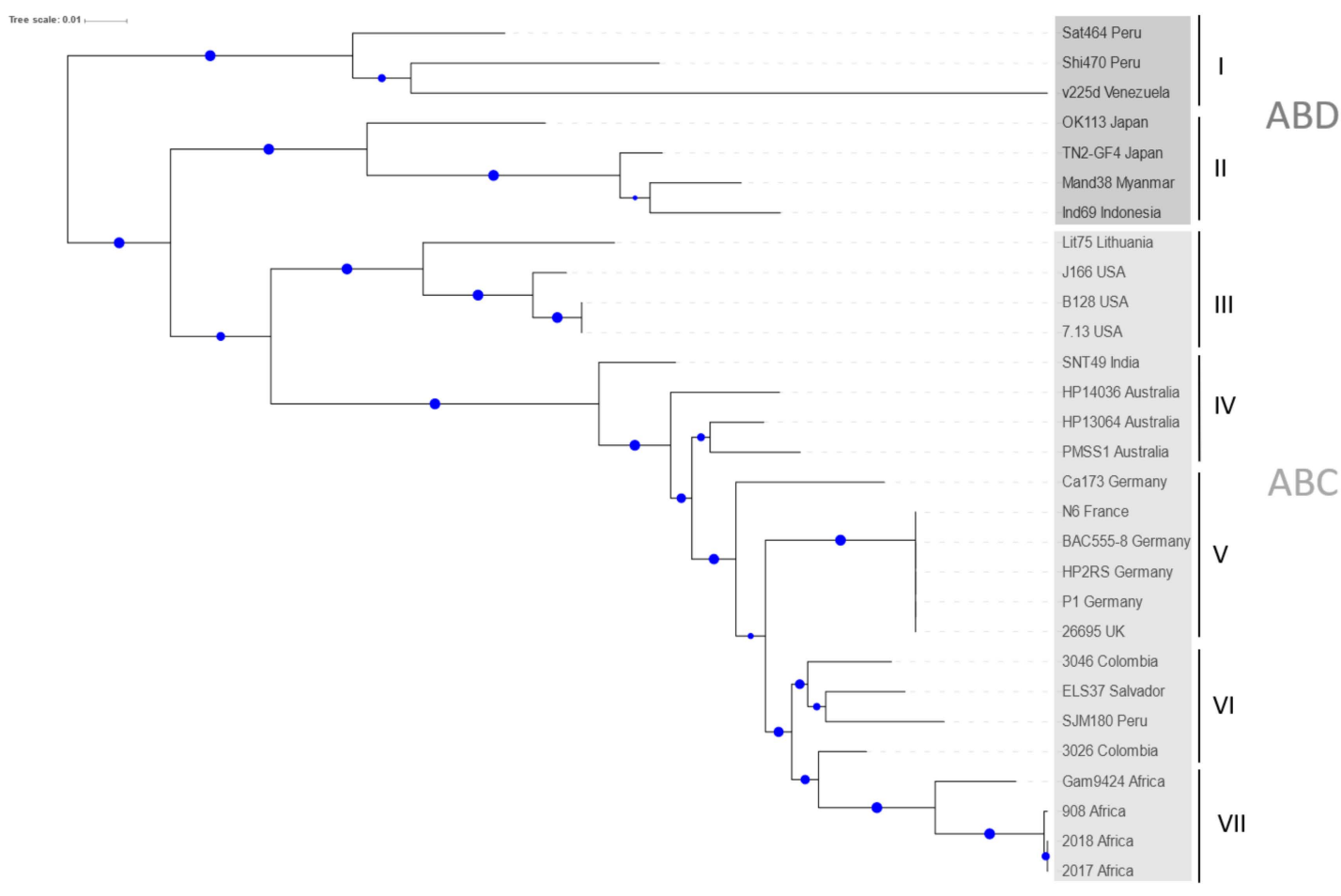

Figure 1. Neighbor-Joining tree of 29 non-redundant CagA protein sequences of patients from all continents. The strain names are indicated with the corresponding country when this information was available. Seven major clusters are identified and labelled with I to VII. Blue dots represent bootstrap values, the larger dots correspond to $100 \%$ and the smaller to $50 \%$, respectively. The grayscale depicts $\mathrm{ABD}$ and $\mathrm{ABC}$ sequence types. The CagA protein sequences were downloaded from GenBank (Supplementary Table S1). For more information see text. 


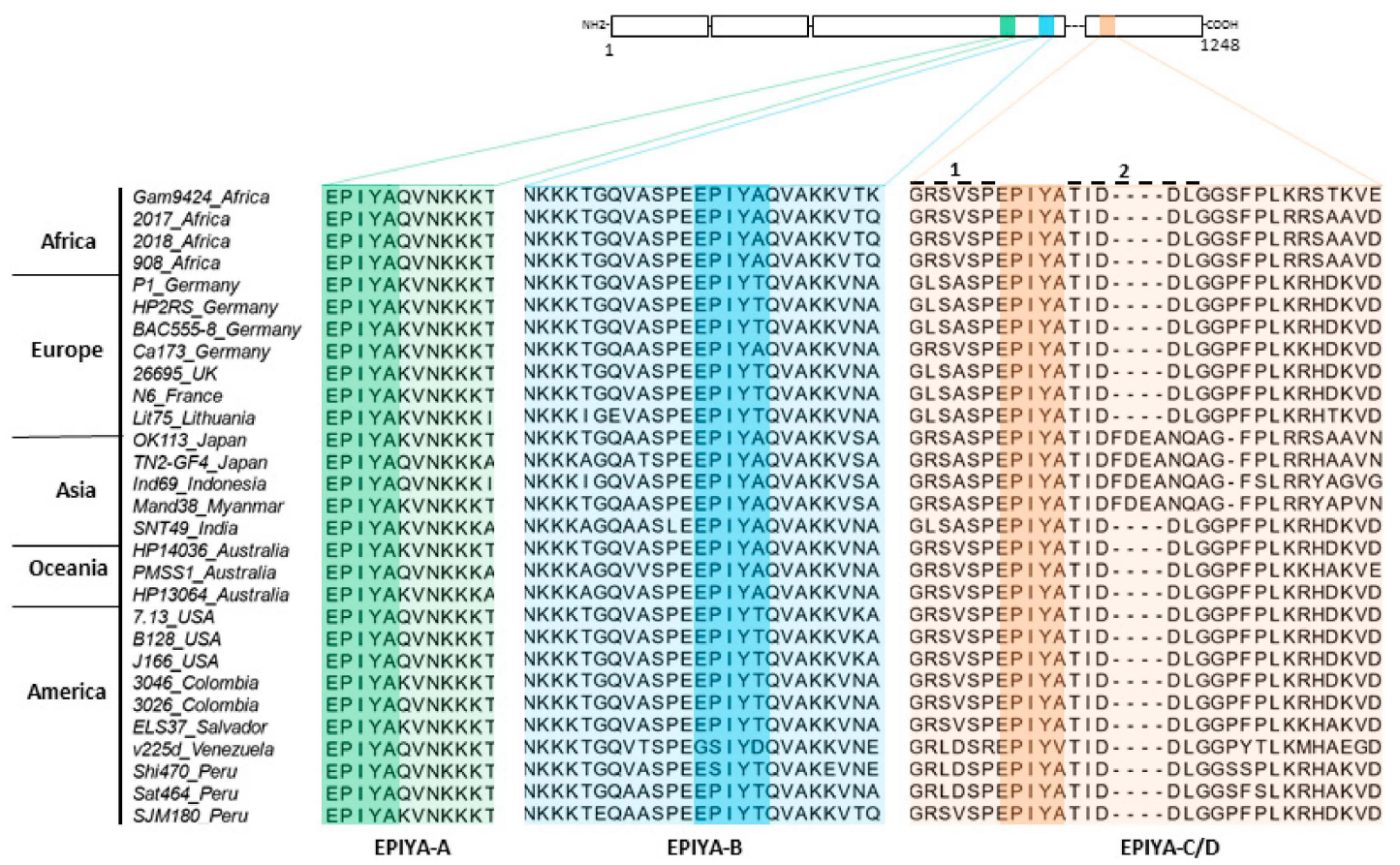

Figure 2. Sequence alignment of the EPIYA-motifs in CagA proteins from worldwide clinical H. pylori strains. Schematic representation of the CagA protein (top) and multiple alignment of a relevant segment (bottom) with color-shaded EPIYA-repeats A, B, and C/D. Variations in their flanking regions were found among clinical H. pylori isolates from different continents, as indicated above the alignment. The CagA protein sequences were downloaded from GenBank (Supplementary Table S1) and sequence alignment was done using ClustalW2 (http://www.ebi.ac.uk/Tools/msa/clustalw2/). For more information see text.

\subsection{Generation of Phosphorylation-Specific Antibodies against EPIYA-Motifs $A, B$, and $C$}

In order to perform a systematic study to investigate the phosphorylation states of CagA, we raised specific antibodies. For this, we synthesized phosphorylated and non-phosphorylated peptides of each EPIYA-site of the model strain 26695. The peptides were designed so that the tyrosine residue that could be phosphorylated was positioned in the middle, flanked by five amino acids on both sides. This resulted in peptides C-STEPIYAKVNK (for EPIYA-A), C-PEEPIYTQVAK (for EPIYA-B), and C-SPEPIYATIDD (for EPIYA-C). A peptide length of 11 amino acids was chosen because peptides of this length are able to generate pan-phosphotyrosine antibodies during immunization, while shorter or longer peptides can result in loss of antibody specificity [48-51]. The peptides were coupled to a carrier protein, Limulus polyphemus haemocyanin (LPH), via an added amino-terminal cysteine residue, and this was used to immunize rabbits, employing two animals per peptide. To select for antibodies specifically recognizing the phosphorylation state of the antigen, all antisera were subjected to immunoglobulin $G$ (IgG) purification columns coupled with the opposing peptide. After this selective removal step, the resulting antibodies were tested for their specificity by dotblots carrying each EPIYA-peptide. As the 11-mer EPIYA-motif C sequence is almost identical to that of EPIYA-motif D (C-SPEPIYATIDF), we also spotted the corresponding EPIYA-D peptides on the dotblots as control. The pan-phosphotyrosine antibody PY-99 was used as a control, as this recognizes all four phosphorylated EPIYA motifs (Figure 3). As shown, the obtained IgG antibodies were not only specific for the EPIYA-A, -B, or -C sequences to which the animals had been immunized, but also for the specific phosphorylation state of these epitopes (Figure 3). The only exception was noted with the antibodies against EPIYA-motif C, which also recognized the closely related EPIYA-D peptides. Thus, the produced antibodies had a strong differentiating specificity for the EPIYA-motifs A, B, and C/D of CagA, and could specifically determine their phosphotyrosine state. 


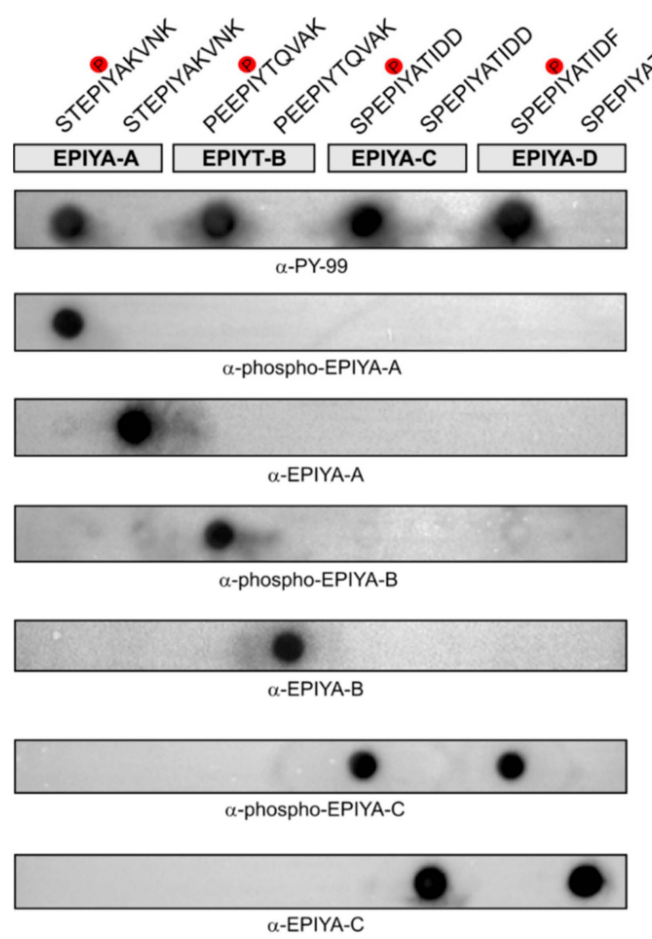

Figure 3. Specific recognition of synthetic 11-mer phospho- and non-phospho-peptides derived from the CagA EPIYA-sites A, B, C, and D by tailor-made antibodies. The indicated phospho- and non-phospho-peptides of the EPIYA-sites were synthesized and blotted onto Immobilon-P membranes using a dotblot system. The peptide sequences cover motifs representing phosphorylation sites, which can be phosphorylated by Src and Abl tyrosine kinases upon infection with $H$. pylori. Membranes with the indicated peptides were probed with the six antibodies generated in this study. Three independent experiments were performed with similar results.

\subsection{Monitoring of Phosphorylated EPIYA-Motifs in Multiple Strains Upon Infection of AGS Cells}

The raised antibodies were used to confirm that they could be used to study the phosphorylation patterns of $\mathrm{CagA}^{\mathrm{PY}}$ proteins during in vitro infection with $H$. pylori. For this purpose, seven representative strains carrying the EPIYA A, B, or C-type CagA obtained from patients from different geographic regions were used to infect AGS cells. The elongation phenotype of the infected cells was examined over a time course to indicate successful CagA delivery [52-54]. After six h, approximately $55-70 \%$ of infected AGS cells exhibited the elongation phenotype, with every individual H. pylori strain tested, indicating that large quantities of $\mathrm{CagA}^{\mathrm{PY}}$ were generated at this time point (Figure 4). The infected cells with attached bacteria were harvested, lysed, and subjected to sodium dodecyl sulfate polyacrylamide gel electrophoresis (SDS-PAGE) and Western blots that were first stained with the pan-phosphotyrosine antibody PY-99 as a positive control (Figure 5A). The different CagA variants revealed slightly different band sizes between 130 and $140 \mathrm{kDa}$, which is in agreement with the variable amino acid sequences of the encoded proteins (Supplementary Table S1). As expected, the control antibody recognized various bands of tyrosine-phosphorylated host cell proteins at approximately 45, 60, 80, 125, and $170 \mathrm{kDa}$ (see full-size blots in Supplementary Figure S1, asterisks). Exposure of the membranes with a commercial $\alpha$-CagA antibody confirmed that similar amounts of CagA were loaded in each lane (Figure 5B, top). The other generated non-phospho CagA antibodies also produced reasonable CagA patterns (Figure 5B, see full-size blots in Supplementary Figure S2). The blots were then probed with the three $\alpha$-phospho EPIYA antibodies, respectively. This resulted in strong bands for phospho-CagA in all seven strains, with very little background signals (Figure 5A). This provides evidence that detectable amounts of individually phosphorylated EPIYA-motifs A, B, and C were present. As a negative control, infection using an isogenic T4SS-deficient Sat $464 \Delta c a g L$ knockout mutant 
was included, which was unable to translocate CagA; this control produced no phospho-signals for CagA (Figure 5A, last lanes), further confirming the specificity of our assays. The obtained signals in the blots were quantitated densitometrically as band intensities and these data are shown in Supplementary Figure S3. The data are expressed as relative intensity with respect to the strongest signal in each panel. As expected, this analysis revealed that the relative quantities of bands obtained for the phospho- and non-phospho CagA variants varied among the strains. The quantification based on the two commercial antibodies did not coincide with that of our EPIYA-specific antibodies. For most of the tested strains, one of the EPIYA-motifs was more strongly detected in the phosphorylated form, while another motif was more dominant in its non-phosphorylated form, but which of the motifs was predominately phosphorylated varied per strain. Despite this considerable variation between strains, as an overall trend we detected stronger EPIYA-C signal intensities compared to the other two variants, independent of their phosphorylation state. Moreover, in most strains the signal for the non-phosphorylated EPIYA-C motif in CagA proteins was stronger than its phosphorylated counterpart. This does not necessarily mean that EPIYA-C was more abundant in the phosphorylated compared to the non-phosphorylated form, as it is possible that the EPIYA-C sequence exhibits a higher immunogenicity potential compared to the other EPIYAs, resulting in stronger antibody signals. Since binding efficiency of the antibodies can be also affected by amino acid differences flanking the EPIYA-motif or even by variable positions in other locations of the protein, differences seen between strains or between antibodies have to be interpreted with caution.

A

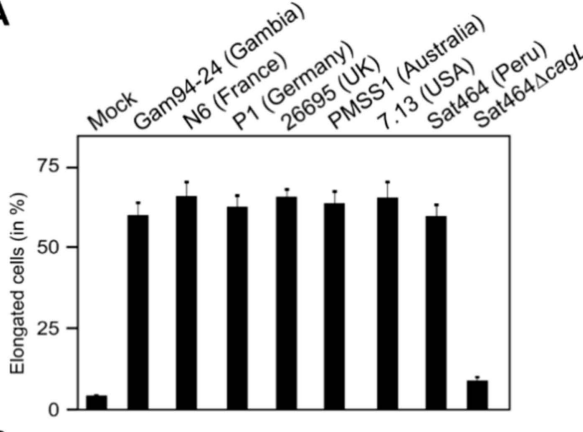

B
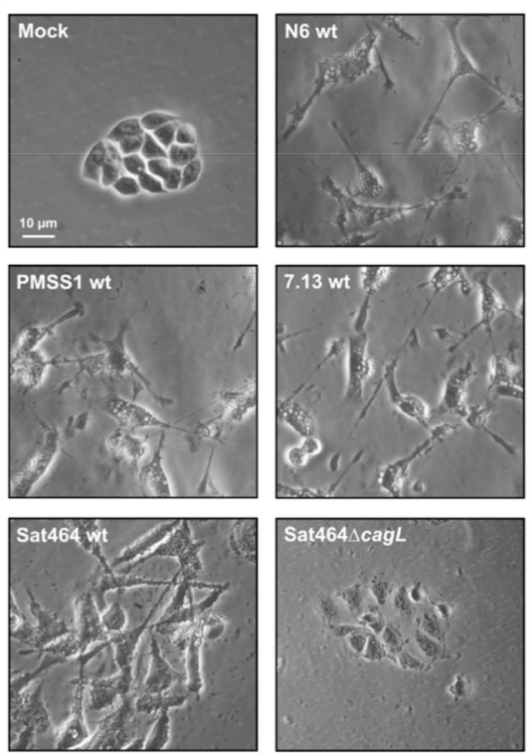

Figure 4. Different clinical H. pylori strains induce AGS cell elongation during infection. The indicated ABC-type CagA H. pylori strains were used to infect AGS cells for $6 \mathrm{~h}$. (A) Quantification of elongated cells was performed in triplicate. Mean values are shown with standard error. (B) Phase contrast microscopy of AGS cells infected with some representative strains is shown. 

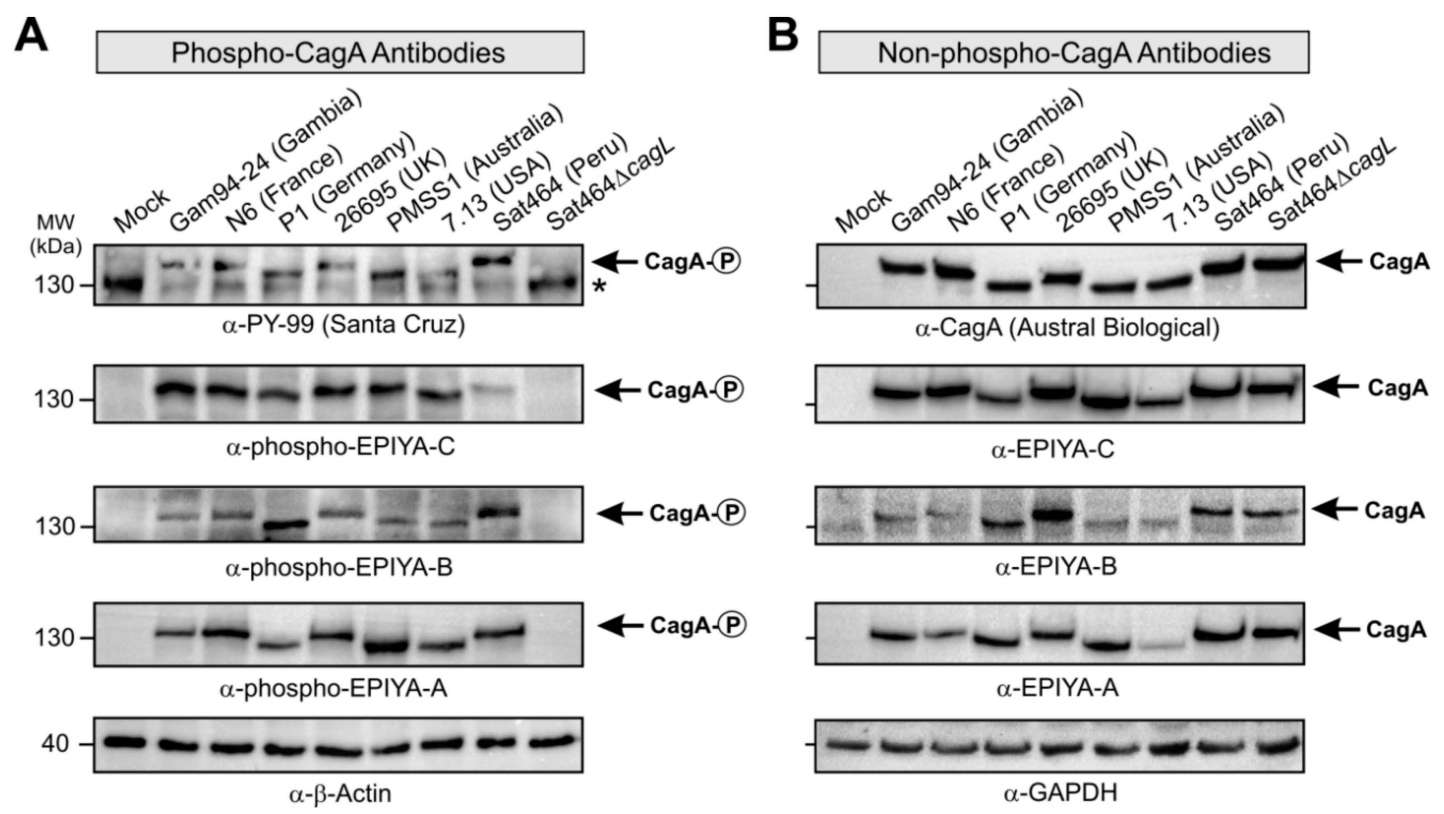

Figure 5. Phosphorylation of CagA EPIYA-motifs during H. pylori infection was investigated using specific $\alpha$-phosphotyrosine antibodies. AGS cells were infected for $6 \mathrm{~h}$ with CagA-expressing H. pylori strains from countries of five continents as indicated. The samples in Figure 3 were collected after photographing and phenotype quantification. Phosphorylation of CagA was examined using the indicated (A) phospho-specific and (B) non-phospho-specific EPIYA antibodies with $\alpha$-PY-99 (Santa Cruz) antibodies as control. Loading of equal amounts of CagA in each sample has been approved by a commercial $\alpha$-CagA antibody (Austral Biologicals). The phospho-CagA bands of different sizes (arrows) as well as a set of tyrosine-phosphorylated host cell proteins (asterisk) are marked. Three independent experiments were performed with similar results. The corresponding uncropped files are shown in Supplementary Figures S1 and S2, respectively, and the statistics are shown in Supplementary Figure S3.

\subsection{Phosphorylation of EPIYA-Motifs in $A B C$ vs. ABD H. Pylori Strains during an Infection Time Course}

Finally, we aimed to study if injected CagA is differentially phosphorylated at certain EPIYA-motifs during a time course of infection. We directly compared $H$. pylori carrying the EPIYA-motif ABC with ABD. For this purpose, we infected AGS cells with the ABC strain 7.13 and ABD strain TN2-GF4-for $45 \mathrm{~min}$ up to $9 \mathrm{~h}$ (Figure 6). Microscopic monitoring of the infected cells revealed gradually increasing numbers of elongated cells over time, suggesting proper CagA translocation (Figure 6A,B). Accordingly, Western blots stained with the three $\alpha$-phospho EPIYA antibodies showed increasing intensities for phospho-CagA bands over time for all EPIYAs in both strains (Figure 6C,D). Most notably, the $\alpha$-phospho EPIYA-C antibody recognized both the phospho-EPIYA-C site in strain 7.13 and the phospho-EPIYA-D site in strain TN2-GF4, which were already detectable as visible bands after 45 min of infection. There were marked differences in band intensities at different time points with the various other antibodies: signals for the phospho-EPIYA-A and -B sites appeared at a later time point than EPIYA-C and became visible only after $90 \mathrm{~min}$, subsequently increasing. Objective quantification of the band intensities of all phospho blots by densitometry confirmed these observations (Figure 6E,F). 
A

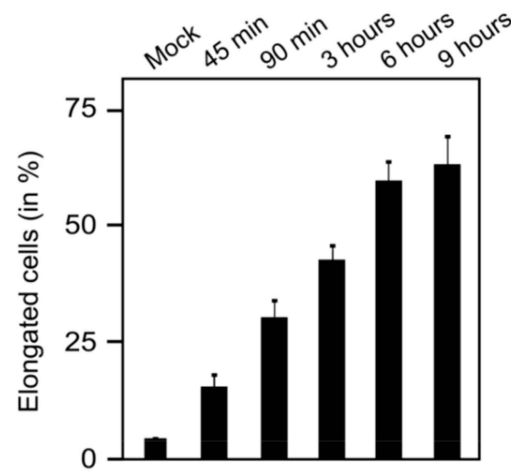

C $\mathrm{MW}$

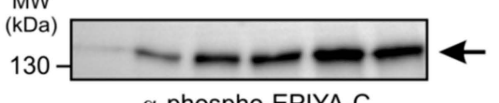

$\alpha$-phospho-EPIYA-C
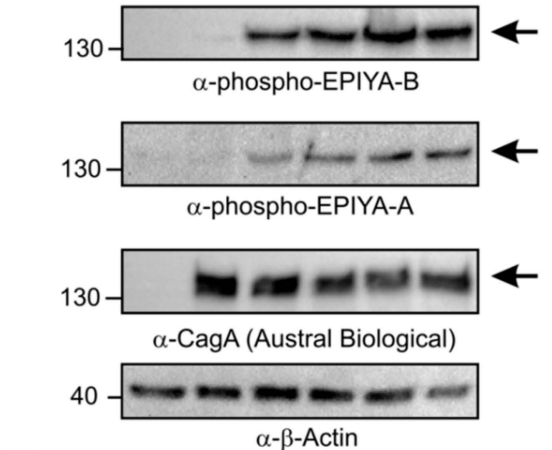

E

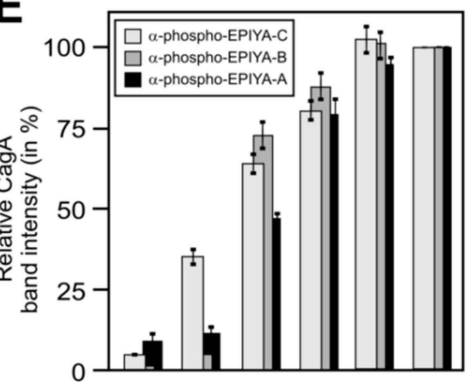

B

TN2-GF4 wt EPIYA-ABD

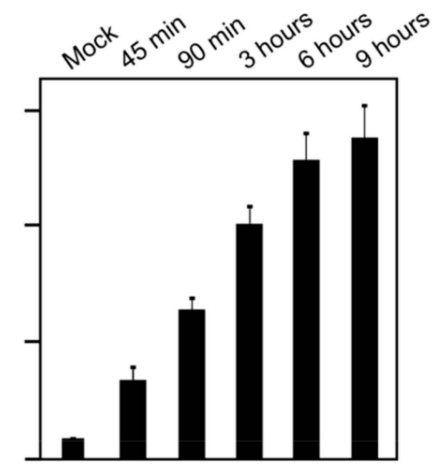

D

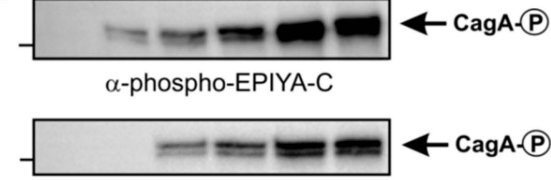

$\alpha$-phospho-EPIYA-B
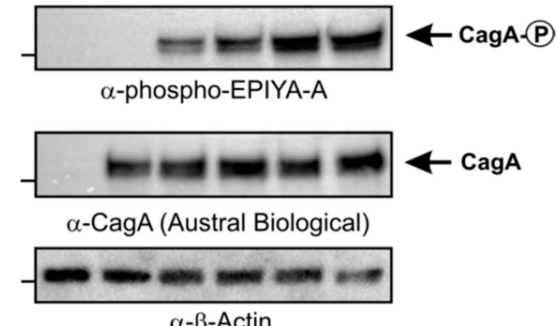

$\mathbf{F}$

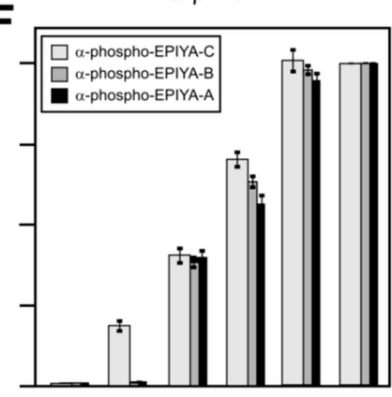

Figure 6. Time-dependent phosphorylation patterns of EPIYA-motifs in H. pylori strains during infection of AGS cells. The ABC-type CagA H. pylori strain 7.13 (A) and ABD-type CagA H. pylori strain TN2-GF4 (B) were used to infect AGS cells for the indicated times. Quantification of elongated cells was performed in triplicate. Mean values are shown with standard error. (C,D) Western blotting was performed using the three indicated $\alpha$-phospho EPIYA antibodies with $\alpha$-CagA and $\alpha$ - $\beta$-Actin as loading controls. (E,F) Quantification of phospho-CagA band intensities in the above blots was performed in triplicate by densitometry. Mean values are shown with standard error.

\section{Discussion}

The T4SS effector protein CagA and its EPIYA-motifs represent crucial virulence determinants of the gastric pathogen $H$. pylori $[2,7,21]$. CagA is the first translocated effector protein in the bacterial kingdom for which a host cell kinase was identified [12,13]. The EPIYA-sites in CagA generally share the small amino acid alanine at the +1 position and an isoleucine at the -1 position, similar to the phosphorylation consensus motif EEIYG/E of Src family kinases [12]. In fact, it was demonstrated that Src as well as Abl tyrosine kinases mediate EPIYA phosphorylation both in vivo and in vitro [12-16,55-57]. However, progress in this research area is mainly hindered by the lack of standardized commercial EPIYA-specific phospho-CagA antibodies, while little information is available about the specificity of 
commercial pan-phosphotyrosine antibodies, such as PY-20, PY-99, and PY-100 [43,44]. Consequently, after two decades of research, unambiguous conclusions on CagA phosphorylation patterns in clinical $H$. pylori isolates during infection are still not available. In this study, we demonstrate the generation of three pairs of $\alpha$-phosphotyrosine antibodies recognizing EPIYA-motifs A, B, and C, respectively, and we have shown that these antibodies display high specificity in recognizing the phosphorylated as well as the non-phosphorylated EPIYA-sites. We confirmed the specificity of each antibody by Western blotting against the corresponding phospho-peptides and excluded cross-reactivity with any non-phospho-peptides. There was only one exception, as antibodies against EPIYA-motif $C$ also recognized the EPIYA-D site. That cross-reactivity could be expected in view of the similarity in amino acid sequence between these sites. Subsequently, infection experiments with $H$. pylori were performed to study the patterns of $\mathrm{CagA}^{\mathrm{PY}}$ following delivery into host cells. These data demonstrate for the first time that each EPIYA-motif can be phosphorylated during infection with both ABC and ABD strains. Together, these results shed new light on the suitability of such antibodies in H. pylori research and pinpoint important new avenues for more detailed analyses on CagA phosphorylation-associated signal transduction events in gastric disease development. For instance, these antibodies may be very useful to study the subcellular localization of individually phosphorylated CagA protein species in cells using high resolution fluorescence microscopy, or they could be applied in immunoprecipitation experiments to identify new host cell binding partners at different phospho-EPIYA motifs.

Remarkably, phosphotyrosine-based signaling is predominant in the domain of higher eukaryotes with many different known kinases involved, such as Src, Abl, EGFR, c-Met, and others, while tyrosine kinases such as the class of BY (bacterial tyrosine) kinases are evolutionary distinct from those in eukaryotes, and some bacteria (including H. pylori) do not encode any known tyrosine kinase [58-60]. As a consequence, phosphotyrosine-dependent protein-protein interactions have been mainly studied in mammals, and various commercially available pan-phosphotyrosine antibodies were initially designed for mammalian proteins [48-51]. These antibodies characteristically recognize short synthetic phospho-peptides. For example, previous investigations have used microarrays with 20,000 spotted human phospho-peptides to depict the binding capacities of three widely applied commercial $\alpha$-pan-phosphotyrosine antibodies, 4G10, PY20, and PY100 [51]. The authors found that each of these antibodies displays a similar binding capacity for phosphotyrosine, but this depends on selected neighboring amino acid residues. Favored binding was observed, with phospho-peptides carrying a leucine at position -1 and proline at position +3 [51]. Interestingly, synthetic phospho-peptides of the CagA EPIYA-sites were shown to be strongly recognized by six commercial pan-phosphotyrosine antibodies $[43,44]$. Using the dotblot approach, we could demonstrate that two of these antibodies (PY20 and PY99) recognized all three phospho-EPIYA peptides A, B, and C with similar and very strong affinity, confirming that this approach also works for peptides derived from a bacterial effector protein $[43,44]$. Other commercial pan-phosphotyrosine antibodies mainly recognized phospho-EPIYA peptides A and C (PY100) or predominantly bound to phospho-EPIYA peptide A, with poor binding to C (PY102) or to $B$ and C (PY69). In combination, the overall results revealed that four pan-phosphotyrosine antibodies (PY20, PY69, PY99, and PY100) recognize a broad reservoir of different phospho-EPIYA motifs. However, in studies of $H$. pylori infected host cells, most of these commercial pan-phosphotyrosine antibodies strongly react with host cell proteins of various size ranges as expected, including even proteins of similar size to CagA ( 120-140 kDa), which severely limits their use for studying specific CagA phosphorylation events in infected cells.

Despite their limitations, pan-phosphotyrosine antibodies have been widely used in early studies to identify phosphorylated CagA by exploring protein lysates of infected cells separated on one-dimensional SDS-PAGE gels [34,39-42]. The results obtained in the current study suggest that each of the CagA EPIYA-sites A, B, C, and D can indeed be phosphorylated during infection. However, the conclusions of those earlier observations, based on one-dimensional gels, are widely imperfect because the resulting bands cannot distinguish how many EPIYA-sites are phosphorylated, or which motive is phosphorylated per single CagA molecule. To overcome this, two-dimensional gel electrophoresis 
was previously employed, which separated different phosphorylated and non-phosphorylated CagA protein spots [23]. Using this strategy and pan-phosphotyrosine antibody PY99, we had already demonstrated that CagA from various strains can be concurrently phosphorylated at one or two EPIYA-motifs per molecule, but never simultaneously at three EPIYA-sites [16,23]. We also determined that Src kinase only phosphorylated EPIYA-C or EPIYA-D, while Abl kinase phosphorylated EPIYA-A, -B, -C, and -D motifs in CagA [16]. Our present study identifies a hierarchic phosphorylation model for CagA starting at EPIYA-C/D, which in our experimental setup was already visible after 45 min of infection, followed by phosphorylation of EPIYA-A or EPIYA-B, which only became visible at later time points. These findings led us to propose that a broad collection of differentially phosphorylated CagA protein molecules are produced in infected host cells, possibly in all possible combinations, which all may have slightly different functions, and this could explain how CagA may coordinate signaling to a high number of different host binding partners [16]. To investigate this assumption in more detail, the EPIYA-specific and phosphorylation-specific CagA antibodies generated in this study will be most useful. However, from the data we present here it cannot yet be concluded whether single CagA molecules can be phosphorylated simultaneously at various positions, which we plan to study in the near future by 2D electrophoresis, as previously described [16]. Moreover, by using Western blotting it cannot be determined how much of the non-phosphorylated CagA detected with infected cells had actually been delivered intracellularly, and how much was residual protein still present inside the adherent bacteria. Lastly, it cannot be excluded that the CagA motifs we detected in host cells with the non-phospho antibodies were originally translocated and present in the phosphorylated form, to be subsequently dephosphorylated by host-derived enzymes. It has been described that host protein tyrosine phosphatases such as SHP1 can display such activity for CagA ${ }^{\mathrm{PY}}$ [61]. Thus, it is possible that the findings during H. pylori infection of AGS cells shown here represent steady state situations that are the result of changing enzymatic activities in the target cells over time.

The present study focused on the phosphorylation of EPIYA-motifs found in CagA of a diverse set of H. pylori strains, for which vast differences were detected, but the findings may be relevant to other bacterial pathogens as well. Tyrosine phosphorylation is a common strategy among bacterial pathogens, although most do not encode their own tyrosine kinases. Enteropathogenic Escherichia coli, Citrobacter rodentium, Bartonella henselae, Chlamydia trachomatis, and Anaplasma phagocytophilum all exhibit a repertoire of remarkable effector proteins (e.g., Tir, BepD, BepE, BepF, Tarp, and AnkA) carrying EPIYA-like motifs that, similar to CagA, become tyrosine-phosphorylated by host cell kinases upon delivery into host cells [7,9,62-64]. Subsequently, these phosphorylated effectors have been shown to bind a selection of cellular interaction partners with Src homology 2 (SH2) domains to manipulate host cell signaling (for reviews see previous work $[9,62,63]$ ). Future investigations will likely focus on the phosphorylation of EPIYA-motifs in each of these bacterial effector proteins, to elucidate any resulting signal transduction events in more detail $[2,4,17,38,64,65]$. For such studies, the generation of antibodies highly specific for each EPIYA-motif and their phosphorylation state is necessary, which we have demonstrated here to be feasible. In the future, this would help to better understand the role of single EPIYA-motifs for bacterial effector protein function and possibly allow correlations and risk predictions for the occurrence of different microbial diseases.

\section{Materials and Methods}

\subsection{Bioinformatic Analysis of CagA Amino Acid Sequences}

The CagA amino acid sequence from H. pylori strain 26695 (accession number WP_000180747) was retrieved from GenBank and used as a query in BlastP against the H. pylori taxon (Taxid: 210) at NCBI. Only CagA entries bearing the EPIYA-motif ABC or ABD type were selected for analysis (Supplementary Table S1). The amino acid sequences were aligned in Muscle [66] and manually edited in Jalview [67]. The evolutionary history of the CagA amino acid sequences was inferred using the Neighbor-Joining method [68] with a statistical robustness for the associated taxa of 1000 replicates 
using the bootstrap test [69]. The evolutionary distances were computed using the JTT matrix-based method, and the rate variation among sites was obtained with a gamma distribution (shape parameter = 2) [70]. The evolutionary analyses were conducted in MEGA7 [71] and the final tree was visualized in Itol [72].

\subsection{H. pylori Strains and Culturing Conditions}

The wild-type H. pylori strains Gam94-24, N6, P1, 26695, PMSS1, 7.13, TN2-GF4, and Sat464 were typical type-I isolates expressing CagA (Supplementary Table S1). The bacteria were grown on horse serum gonococcal (GC) agar plates containing vancomycin $(10 \mu \mathrm{g} / \mathrm{mL})$, nystatin $(1 \mu \mathrm{g} / \mathrm{mL})$, and trimethoprim $(5 \mu \mathrm{g} / \mathrm{mL})$, and in the case of mutants kanamycin $(8 \mu \mathrm{g} / \mathrm{mL})$, as described previously $[73,74]$. Mutagenesis of the $c a g L$ gene was performed by insertion of a kanamycin resistance gene cassette as described [75]. All antibiotics were obtained from Sigma-Aldrich. Bacteria were grown at $37^{\circ} \mathrm{C}$ for 2 days in an anaerobic jar containing a Campygen gas mix of $5 \% \mathrm{O}_{2}, 10 \% \mathrm{CO}_{2}$, and $85 \% \mathrm{~N}_{2}$ (Oxoid, Wesel, Germany) [76,77].

\subsection{Production of Phospho-and Non-Phospho-Specific EPIYA Antibodies}

The following peptide sequences were synthesized by Jerini (Berlin, Germany): C-STEPIYAKVNK (EPIYA-A), C-STEPI(pY)AKVNK (phospho-EPIYA-A), C-PEEPIYTQVAK (EPIYA-B), C-PEEPI(pY)TQVAK (phospho-EPIYA-B), C-SPEPIYATIDD (EPIYA-C), and C-SPEPI(pY)ATIDD (phospho-EPIYA-C). The peptides C-SPEPIYATIDF (EPIYA-D) and C-SPEPI(pY)ATIDF (phospho-EPIYA-D) were synthesized for use of as controls. Each of these EPIYA peptides was purified by High Performance Liquid Chromatography (HPLC) and their purity was approved by mass spectrometry analysis (Jerini, Berlin, Germany). All peptides were synthesized with an additional amino-terminal cysteine residue to which Limulus polyphemus haemocyanin (LPH) carrier protein was conjugated (Biogenes, Berlin, Germany). Two rabbits were immunized with each conjugated peptide according to a standard protocol by Biogenes using an immunization schedule summarized in Table 1. The resulting antisera were used to select phospho-specific antibodies by affinity-removal of the corresponding non-phospho-peptide of each EPIYA-motif bound to a column. Conversely, the obtained non-phospho antibodies were affinity-purified using columns against the corresponding phospho-peptide. These antibodies were prepared on a customer basis and purified by Biogenes.

Table 1. Time scheme of rabbit immunization.

\begin{tabular}{cc}
\hline Day & Step \\
\hline 0 & Peptide synthesis and LPH coupling \\
0 & Collection of pre-immune serum \\
0 & First immunization of 2 rabbits \\
7 & First boost \\
14 & Second boost \\
28 & Third boost \\
42 & Bleeding, fourth boost \\
56 & Fifth boost \\
70 & Sixth boost \\
77 & Bleeding \\
105 & Final bleeding, serum IgG purification \\
\hline
\end{tabular}

\subsection{Dotblot Analysis}

Dotblots were prepared by spotting $20 \mu \mathrm{g}$ of each peptide in $1 \mathrm{~mL}$ of transfer buffer $(192 \mathrm{mM}$ Glycine; 20 mM Tris-HCl, pH 8.4; 0.1\% SDS; 20\% Methanol) onto Immobilon-P membrane (Millipore, Darmstadt, Germany) using the BioDot apparatus (BioRad, Munich, Germany) [78,79]. The resulting dotblots were dried at $37^{\circ} \mathrm{C}$ and subjected to antibody detection by Western blots, as described below. 


\subsection{Host Cell Culture, Infection Assays, and Elongation Phenotype Quantitation}

The human gastric adenocarcinoma cell line AGS (ATCC CRL-1739 ${ }^{\mathrm{TM}}$ ) was cultured on 6-well plates in RPMI1640 medium (Invitrogen, Karlsruhe, Germany) supplemented with 10\% fetal calf serum (Invitrogen) and a penicillin/streptomycin cocktail (Sigma-Aldrich, Taufkirchen, Germany). The cells were grown in $5 \%(v / v) \mathrm{CO}_{2}$ at $37{ }^{\circ} \mathrm{C}[80,81]$. When the cells reached about $75 \%$ confluency, they were washed two times with Phosphate Buffered Saline (PBS) and fresh RPMI1640 medium without antibiotics was added [82,83]. Cells were serum-deprived overnight and infected with H. pylori at a multiplicity of infection (MOI) of 50 for $6 \mathrm{~h}$. After infection, the cells were harvested in ice-cold PBS containing $1 \mathrm{mmol} / 1 \mathrm{Na}_{3} \mathrm{VO}_{4}$ (Sigma-Aldrich). Using an Olympus IX50 phase contrast microscope, the elongated AGS cells were quantitated in 10 different $0.25-\mathrm{mm}^{2}$ fields per experiment $[84,85]$. All experiments were done in triplicate.

\subsection{SDS-PAGE and Western Blotting}

Infected AGS cells were washed twice with PBS to remove unbound bacteria, and then the cells were harvested with attached bacteria, pelleted, and resuspended in equal amounts of $2 \times$ SDS-PAGE buffer. Proteins were boiled for $5 \mathrm{~min}$ and then subjected to SDS-PAGE. The proteins were resolved in $6 \%$ polyacrylamide gels and blotted onto Immobilon-P membranes (Millipore). Membranes were blocked in Tris-buffered saline with Tween 20 (TBST) buffer with $3 \%$ bovine serum albumin (BSA) or $5 \%$ skim milk for $1 \mathrm{~h}$ at room temperature followed by incubation with the generated $\alpha$-phosphotyrosine and non-phospho CagA antibodies [86,87]. As controls, we used a rabbit polyclonal $\alpha$-CagA antibody (Austral Biologicals, San Ramon, CA, USA) and the mouse monoclonal pan-phosphotyrosine antibody PY-99 (Santa Cruz, Dallas, TX, USA) according to the instructions by the manufacturers. Phosphorylated and non-phosphorylated CagA proteins were detected using horseradish peroxidase-conjugated anti-rabbit or anti-mouse polyvalent goat immunoglobulin secondary antibodies visualized by the Amersham enhanced chemiluminescence (ECL) Prime Western blot kit (GE Healthcare, Munich, Germany), as described previously [88,89].

\subsection{Statistical Analysis}

The intensities of the Western blot signals, derived from three independent experiments, were measured and quantitated densitometrically by the Image Lab ${ }^{\mathrm{TM}}$ software (Bio-Rad). For each $\alpha$-phosphotyrosine and $\alpha$-non-phospho CagA/EPIYA Western blot, shown in Figures 5 and $6 \mathrm{C}, \mathrm{D}$, the strongest band on the gels was set to $100 \%$ and the relative intensities of every single band on the respective blot were calculated (Supplementary Figure S3 and Figure 6E,F). The error bars for quantifying relative band intensities in Supplementary Figure S3 and number of elongated cells shown in Figure 4 represent the standard error of the mean (SEM) calculated with Excel software.

\section{Conclusions}

All commercially available pan-phosphotyrosine antibodies were originally produced to detect a wide array of phosphotyrosines in multiple mammalian proteins, but were not optimized for usage in bacterial effector proteins. Here we generated 11-mer phospho- and non-phospho-peptides from the EPIYA-motifs A, B, and C of $H$. pylori CagA, and produced three phospho-specific and three non-phospho-specific polyclonal antibodies in rabbits. We demonstrated that these antibodies specifically detect the corresponding phosphorylated and non-phosphorylated EPIYA-motifs. Interestingly, the EPIYA-C antibodies also recognized the closely related East-Asian motif EPIYA-D in vitro. Furthermore, we showed that each EPIYA-motif can be efficiently phosphorylated during infection with $H$. pylori $\mathrm{ABC}$ and $\mathrm{ABD}$ strains in vivo. Together, we present here the first complete set of phospho-specific antibodies for a bacterial effector protein, which are new beneficial tools to collect important data for cataloguing CagA phosphorylation events, disease development in the human stomach and gastric cancer signal transduction. 
Supplementary Materials: The following are available online at http://www.mdpi.com/2072-6694/11/8/1163/s1. Table S1: Worldwide CagA protein sequences analyzed in the study, Figure S1: CagA EPIYA-motif phosphorylation during $H$. pylori infection of AGS cells was investigated using the indicated $\alpha$-phosphotyrosine antibodies, Figure S2: CagA expression during H. pylori infection of AGS cells was investigated using the indicated $\alpha$-CagA and $\alpha$-EPIYA antibodies, Figure S3: Statistics of CagA EPIYA-motif phosphorylation and expression of CagA during H. pylori infection of AGS cells.

Author Contributions: Conceptualization, N.T.; methodology N.T., A.J.G.-E., and S.K.P.; investigation, S.K.P., N.T., and A.J.G.-E.; writing—original draft preparation, N.T.; writing—review and editing, A.J.G.-E. and S.K.P.; visualization, N.T.; supervision, N.T.; project administration, N.T.; funding acquisition, N.T.

Funding: This research was funded by the German Science Foundation (DFG) grant TE776/3-1 to N.T.

Acknowledgments: We thank Wilhelm Brill and Nina Rottmann for excellent technical assistance, and Steffen Backert (all FAU Erlangen) for general advise. The support by Douglas Berg (University of Southern California, San Diego, USA) for providing H. pylori strains Gam94-24 and Sat464, Anna Zawilak-Pawlik (Hirszfeld Institute, Wrocław, Poland) for strains 26695 and N6, Anne Müller (University of Zürich, Switzerland) for PMSS1, and Richard Peek (Vanderbilt University, Nashville, USA) for 7.13 and TN2-GF4, which was very much appreciated. We acknowledge support by Deutsche Forschungsgemeinschaft and Friedrich-Alexander-Universität Erlangen-Nürnberg (FAU) within the funding program Open Access Publishing.

Conflicts of Interest: The authors declare no conflict of interest. The funders had no role in the design of the study; in the collection, analyses, or interpretation of data; in the writing of the manuscript, or in the decision to publish the results.

\section{References}

1. Covacci, A.; Rappuoli, R. Tyrosine-phosphorylated bacterial proteins: Trojan horses for the host cell. J. Exp. Med. 2000, 191, 587-592. [CrossRef] [PubMed]

2. Hatakeyama, M. Helicobacter pylori and gastric carcinogenesis. J. Gastroenterol. 2009, 44, 239-248. [CrossRef] [PubMed]

3. Yamaoka, Y. Mechanisms of disease: Helicobacter pylori virulence factors. Nat. Rev. Gastroenterol. Hepatol. 2009, 7, 629-641. [CrossRef] [PubMed]

4. $\quad$ Backert, S.; Haas, R.; Gerhard, M.; Naumann, M. The Helicobacter pylori Type IV Secretion System Encoded by the cag Pathogenicity Island: Architecture, Function, and Signaling. Curr. Top. Microbiol. Immunol. 2017, 413, 187-220. [PubMed]

5. Kwok, T.; Zabler, D.; Urman, S.; Rohde, M.; Hartig, R.; Wessler, S.; Misselwitz, R.; Berger, J.; Sewald, N.; König, W.; et al. Helicobacter exploits integrin for type IV secretion and kinase activation. Nature 2007, 449, 862-866. [CrossRef] [PubMed]

6. Chang, Y.W.; Shaffer, C.L.; Rettberg, L.A.; Ghosal, D.; Jensen, G.J. In Vivo Structures of the Helicobacter pylori cag Type IV Secretion System. Cell Rep. 2018, 23, 673-681. [CrossRef]

7. Backert, S.; Tegtmeyer, N.; Selbach, M. The versatility of Helicobacter pylori CagA effector protein functions: The master key hypothesis. Helicobacter 2010, 15, 163-176. [CrossRef]

8. Kaplan-Türköz, H.; Jiménez-Soto, L.F.; Dian, C.; Ertl, C.; Remaut, H.; Louche, A.; Tosi, T.; Haas, R.; Terradot, L. Structural insights into Helicobacter pylori oncoprotein CagA interaction with $\beta 1$ integrin. Proc. Natl. Acad. Sci. USA 2012, 109, 14640-14645. [CrossRef]

9. Hayashi, T.; Morohashi, H.; Hatakeyama, M. Bacterial EPIYA effectors-where do they come from? What are they? Where are they going? Cell Microbiol. 2013, 15, 377-385. [CrossRef]

10. Botham, C.M.; Wandler, A.M.; Guillemin, K.A. Transgenic Drosophila model demonstrates that the Helicobacter pylori CagA protein functions as a eukaryotic Gab adaptor. PLoS Pathog. 2008, 4, e1000064. [CrossRef]

11. Tegtmeyer, N.; Neddermann, M.; Asche, C.I.; Backert, S. Subversion of host kinases: A key network in cellular signaling hijacked by Helicobacter pylori CagA. Mol. Microbiol. 2017, 105, 358-372. [CrossRef] [PubMed]

12. Selbach, M.; Moese, S.; Hauck, C.R.; Meyer, T.F.; Backert, S. Src is the kinase of the Helicobacter pylori CagA protein in vitro and in vivo. J. Biol. Chem. 2002, 277, 6775-6778. [CrossRef] [PubMed]

13. Stein, M.; Bagnoli, F.; Halenbeck, R.; Rappuoli, R.; Fantl, W.J.; Covacci, A. c-Src/Lyn kinases activate Helicobacter pylori CagA through tyrosine phosphorylation of the EPIYA motifs. Mol. Microbiol. 2002, 43, 971-980. [CrossRef] [PubMed]

14. Poppe, M.; Feller, S.M.; Römer, G.; Wessler, S. Phosphorylation of Helicobacter pylori CagA by c-Abl leads to cell motility. Oncogene 2007, 26, 3462-3472. [CrossRef] [PubMed] 
15. Tammer, I.; Brandt, S.; Hartig, R.; König, W.; Backert, S. Activation of Abl by Helicobacter pylori: A novel kinase for CagA and crucial mediator of host cell scattering. Gastroenterology 2007, 132, 1309-1319. [CrossRef] [PubMed]

16. Mueller, D.; Tegtmeyer, N.; Brandt, S.; Yamaoka, Y.; De Poire, E.; Sgouras, D.; Wessler, S.; Torres, J.; Smolka, A.; Backert, S. c-Src and c-Abl kinases control hierarchic phosphorylation and function of the CagA effector protein in Western and East Asian Helicobacter pylori strains. J. Clin. Investig. 2012, 122, 1553-1566. [CrossRef] [PubMed]

17. Grohmann, E.; Christie, P.J.; Waksman, G.; Backert, S. Type IV secretion in Gram-negative and Gram-positive bacteria. Mol. Microbiol. 2018, 107, 455-471. [CrossRef]

18. Backert, S.; Moese, S.; Selbach, M.; Brinkmann, V.; Meyer, T.F. Phosphorylation of tyrosine 972 of the Helicobacter pylori CagA protein is essential for induction of a scattering phenotype in gastric epithelial cells. Mol. Microbiol. 2001, 42, 631-644. [CrossRef]

19. Mimuro, H.; Suzuki, T.; Tanaka, J.; Asahi, M.; Haas, R.; Sasakawa, C. Grb2 is a key mediator of Helicobacter pylori CagA protein activities. Mol. Cell. 2002, 10, 745-755. [CrossRef]

20. Higashi, H.; Tsutsumi, R.; Muto, S.; Sugiyama, T.; Azuma, T.; Asaka, M.; Hatakeyama, M. SHP2 tyrosine phosphatase as an intracellular target of Helicobacter pylori CagA protein. Science 2002, 295, 683-686. [CrossRef]

21. Xia, Y.; Yamaoka, Y.; Zhu, Q.; Matha, I.; Gao, X. A comprehensive sequence and disease correlation analyses for the C-terminal region of CagA protein of Helicobacter pylori. PLoS ONE 2009, 4, e7736. [CrossRef] [PubMed]

22. Furuta, Y.; Yahara, K.; Hatakeyama, M.; Kobayashi, I. Evolution of cagA oncogene of Helicobacter pylori through recombination. PLoS ONE 2011, 6, e23499. [CrossRef] [PubMed]

23. Backert, S.; Müller, E.C.; Jungblut, P.R.; Meyer, T.F. Tyrosine phosphorylation patterns and size modification of the Helicobacter pylori CagA protein after translocation into gastric epithelial cells. Proteomics 2001, 1, 608-617. [CrossRef]

24. Aras, R.A.; Lee, Y.; Kim, S.K.; Israel, D.; Peek, R.M., Jr.; Blaser, M.J. Natural variation in populations of persistently colonizing bacteria affect human host cell phenotype. J. Infect. Dis. 2003, 188, 486-496.

25. Argent, R.H.; Zhang, Y.; Atherton, J. Simple method for determination of the number of Helicobacter pylori CagA variable-region EPIYA tyrosine phosphorylation motifs by PCR. J. Clin. Microbiol. 2005, 43, 791-795. [CrossRef] [PubMed]

26. Kim, S.Y.; Lee, Y.C.; Kim, H.K.; Blaser, M.J. Helicobacter pylori CagA transfection of gastric epithelial cells induces interleukin-8. Cell. Microbiol. 2006, 8, 97-106. [CrossRef] [PubMed]

27. Naito, M.; Yamazaki, T.; Tsutsumi, R.; Higashi, H.; Onoe, K.; Yamazaki, S.; Azuma, T.; Hatakeyama, M. Influence of EPIYA-repeat polymorphism on the phosphorylation-dependent biological activity of Helicobacter pylori CagA. Gastroenterology 2006, 130, 1181-1190. [CrossRef]

28. Panayotopoulou, E.G.; Sgouras, D.N.; Papadakos, K.; Kalliaropoulos, A.; Papatheodoridis, G.; Mentis, A.F.; Archimandritis, A.J. Strategy to characterize the number and type of repeating EPIYA phosphorylation motifs in the carboxyl terminus of CagA protein in Helicobacter pylori clinical isolates. J. Clin. Microbiol. 2007, 45, 488-495. [CrossRef]

29. Basso, D.; Zambon, C.F.; Letley, D.P.; Stranges, A.; Marchet, A.; Rhead, J.L.; Schiavon, S.; Guariso, G.; Ceroti, M.; Nitti, D.; et al. Clinical relevance of Helicobacter pylori cagA and vacA gene polymorphisms. Gastroenterology 2008, 135, 91-99. [CrossRef]

30. Schmidt, H.M.; Goh, K.L.; Fock, K.M.; Hilmi, I.; Dhamodaran, S.; Forman, D.; Mitchell, H. Distinct cagA EPIYA motifs are associated with ethnic diversity in Malaysia and Singapore. Helicobacter 2009, 14, 256-263. [CrossRef]

31. Miura, M.; Ohnishi, N.; Tanaka, S.; Yanagiya, K.; Hatakeyama, M. Differential oncogenic potential of geographically distinct Helicobacter pylori CagA isoforms in mice. Int. J. Cancer 2009, 125, 2497-2504. [CrossRef] [PubMed]

32. Truong, B.X.; Mai, V.T.; Tanaka, H.; Ly, L.T.; Thong, T.M.; Hai, H.H.; Van Long, D.; Furumatsu, K.; Yoshida, M.; Kutsumi, H.; et al. Diverse characteristics of the CagA gene of Helicobacter pylori strains collected from patients from southern Vietnam with gastric cancer and peptic ulcer. J. Clin. Microbiol. 2009, 47, 4021-4028. [CrossRef] [PubMed] 
33. Jones, K.R.; Joo, Y.M.; Jang, S.; Yoo, Y.J.; Lee, H.S.; Chung, I.S.; Olsen, C.H.; Whitmire, J.M.; Merrell, D.S.; Cha, J.H. Polymorphism in the CagA EPIYA motif impacts development of gastric cancer. J. Clin. Microbiol. 2009, 47, 959-968. [CrossRef] [PubMed]

34. Segal, E.D.; Cha, J.; Lo, J.; Falkow, S.; Tompkins, L.S. Altered states: Involvement of phosphorylated CagA in the induction of host cellular growth changes by Helicobacter pylori. Proc. Natl. Acad. Sci. USA 1999, 96, 14559-14564. [CrossRef] [PubMed]

35. Churin, Y.; Al-Ghoul, L.; Keep, O.; Meyer, T.F.; Birchmeier, W.; Naumann, M. Helicobacter pylori CagA protein targets the c-Met receptor and enhances the motogenic response. J. Cell. Biol. 2003, 161, 249-255. [CrossRef] [PubMed]

36. Selbach, M.; Moese, S.; Meyer, T.F.; Backert, S. Functional analysis of the Helicobacter pylori cag pathogenicity island reveals both VirD4-CagA-dependent and VirD4-CagA-independent mechanisms. Infect. Immun. 2002, 70, 6656-6671. [CrossRef]

37. Selbach, M.; Moese, S.; Hurwitz, R.; Hauck, C.R.; Meyer, T.F.; Backert, S. The Helicobacter pylori CagA protein induces cortactin dephosphorylation and actin rearrangement by c-Src inactivation. EMBO J. 2003, 22, 515-528. [CrossRef]

38. Naumann, M.; Sokolova, O.; Tegtmeyer, N.; Backert, S. Helicobacter pylori: A Paradigm Pathogen for Subverting Host Cell Signal Transmission. Trends Microbiol. 2017, 25, 316-328. [CrossRef]

39. Odenbreit, S.; Püls, J.; Sedlmaier, B.; Gerland, E.; Fischer, W.; Haas, R. Translocation of Helicobacter pylori CagA into gastric epithelial cells by type IV secretion. Science 2000, 287, 1497-1500. [CrossRef]

40. Stein, M.; Rappuoli, R.; Covacci, A. Tyrosine phosphorylation of the Helicobacter pylori CagA antigen after cag-driven host cell translocation. Proc. Natl. Acad. Sci. USA 2000, 97, 1263-1268. [CrossRef]

41. Asahi, M.; Azuma, T.; Ito, S.; Ito, Y.; Suto, H.; Nagai, Y.; Tsubokawa, M.; Tohyama, Y.; Maeda, S.; Omata, M.; et al. Helicobacter pylori CagA protein can be tyrosine phosphorylated in gastric epithelial cells. J. Exp. Med. 2000, 191, 593-602. [PubMed]

42. Backert, S.; Ziska, E.; Brinkmann, V.; Zimny-Arndt, U.; Fauconnier, A.; Jungblut, P.R.; Naumann, M.; Meyer, T.F. Translocation of the Helicobacter pylori CagA protein in gastric epithelial cells by a type IV secretion apparatus. Cell. Microbiol. 2000, 2, 155-164. [CrossRef] [PubMed]

43. Lind, J.; Backert, S.; Pfleiderer, K.; Berg, D.E.; Yamaoka, Y.; Sticht, H.; Tegtmeyer, N. Systematic analysis of phosphotyrosine antibodies recognizing single phosphorylated EPIYA-motifs in CagA of Western-type Helicobacter pylori strains. PLoS ONE 2014, 9, e96488. [CrossRef] [PubMed]

44. Lind, J.; Backert, S.; Hoffmann, R.; Eichler, J.; Yamaoka, Y.; Perez-Perez, G.I.; Torres, J.; Sticht, H.; Tegtmeyer, N. Systematic analysis of phosphotyrosine antibodies recognizing single phosphorylated EPIYA-motifs in CagA of East Asian-type Helicobacter pylori strains. BMC Microbiol. 2016, 16, 201. [CrossRef] [PubMed]

45. Asahi, M.; Tanaka, Y.; Izumi, T.; Ito, Y.; Naiki, H.; Kersulyte, D.; Tsujikawa, K.; Saito, M.; Sada, K.; Yanagi, S.; et al. Helicobacter pylori CagA containing ITAM-like sequences localized to lipid rafts negatively regulates VacA-induced signaling in vivo. Helicobacter 2003, 8, 1-14. [CrossRef] [PubMed]

46. Zhang, X.S.; Tegtmeyer, N.; Traube, L.; Jindal, S.; Perez-Perez, G.; Sticht, H.; Backert, S.; Blaser, M.J. A specific A/T polymorphism in Western tyrosine phosphorylation B-motifs regulates Helicobacter pylori CagA epithelial cell interactions. PLoS Pathog. 2015, 11, e1004621. [CrossRef] [PubMed]

47. Moodley, Y.; Linz, B. Helicobacter pylori Sequences Reflect Past Human Migrations. Genome Dyn. 2009, 6, 62-74.

48. Blaydes, J.P.; Vojtesek, B.; Bloomberg, G.B.; Hupp, T.R. The development and use of phospho-specific antibodies to study protein phosphorylation. Methods Mol. Biol. 2000, 99, 177-189.

49. Houseman, B.T.; Huh, J.H.; Kron, S.J.; Mrksich, M. Peptide chips for the quantitative evaluation of protein kinase activity. Nat. Biotechnol. 2002, 20, 270-274. [CrossRef]

50. Kim, M.; Shin, D.S.; Kim, J.; Lee, Y.S. Substrate screening of protein kinases: Detection methods and combinatorial peptide libraries. Biopolymers 2010, 94, 753-762. [CrossRef]

51. Tinti, M.; Nardozza, A.P.; Ferrari, E.; Sacco, F.; Corallino, S.; Cesareni, G. The 4G10, pY20 and p-TYR-100 antibody specificity: Profiling by peptide microarrays. Nat. Biotechnol. 2012, 29, 571-577. [CrossRef] [PubMed]

52. Backert, S.; Schwarz, T.; Miehlke, S.; Kirsch, C.; Sommer, C.; Kwok, T.; Gerhard, M.; Goebel, U.B.; Lehn, N.; Koenig, W.; et al. Functional analysis of the cag pathogenicity island in Helicobacter pylori isolates from patients with gastritis, peptic ulcer, and gastric cancer. Infect. Immun. 2004, 72, 1043-1056. [CrossRef] [PubMed] 
53. Brandt, S.; Wessler, S.; Hartig, R.; Backert, S. Helicobacter pylori activates protein kinase C delta to control Raf in MAP kinase signalling: Role in AGS epithelial cell scattering and elongation. Cell Motil. Cytoskelet. 2009, 66, 874-892. [CrossRef]

54. Tegtmeyer, N.; Zabler, D.; Schmidt, D.; Hartig, R.; Brandt, S.; Backert, S. Importance of EGF receptor, HER2/Neu and Erk1/2 kinase signalling for host cell elongation and scattering induced by the Helicobacter pylori CagA protein: Antagonistic effects of the vacuolating cytotoxin VacA. Cell. Microbiol. 2009, 11, 488-505. [CrossRef] [PubMed]

55. Posselt, G.; Backert, S.; Wessler, S. The functional interplay of Helicobacter pylori factors with gastric epithelial cells induces a multi-step process in pathogenesis. Cell Commun. Signal. 2013, 11, 77. [CrossRef] [PubMed]

56. Wessler, S.; Backert, S. Abl family of tyrosine kinases and microbial pathogenesis. Int. Rev. Cell Mol. Biol. 2011, 286, 271-300. [PubMed]

57. Backert, S.; Feller, S.M.; Wessler, S. Emerging roles of Abl family tyrosine kinases in microbial pathogenesis. Trends Biochem. Sci. 2008, 33, 80-90. [CrossRef]

58. Hunter, T. Tyrosine phosphorylation: Thirty years and counting. Curr. Opin. Cell Biol. 2009, 21, 140-146. [CrossRef]

59. Shi, L.; Ji, B.; Kolar-Znika, L.; Boskovic, A.; Jadeau, F.; Combet, C.; Grangeasse, C.; Franjevic, D.; Talla, E.; Mijakovic, I. Evolution of bacterial protein-tyrosine kinases and their relaxed specificity toward substrates. Genome Biol. Evol. 2014, 6, 800-817. [CrossRef]

60. Alm, R.A.; Trust, T.J. Analysis of the genetic diversity of Helicobacter pylori: The tale of two genomes. J. Mol. Med. (Berl.) 1999, 77, 834-846. [CrossRef]

61. Saju, P.; Murata-Kamiya, N.; Hayashi, T.; Senda, Y.; Nagase, L.; Noda, S.; Matsusaka, K.; Funata, S.; Kunita, A.; Urabe, M.; et al. Host SHP1 phosphatase antagonizes Helicobacter pylori CagA and can be downregulated by Epstein-Barr virus. Nat. Microbiol. 2016, 1, 16026. [CrossRef] [PubMed]

62. Backert, S.; Selbach, M. Tyrosine-phosphorylated bacterial effector proteins: The enemies within. Trends Microbiol. 2005, 13, 476-484. [CrossRef] [PubMed]

63. Selbach, M.; Paul, F.E.; Brandt, S.; Guye, P.; Daumke, O.; Backert, S.; Dehio, C.; Mann, M. Host cell interactome of tyrosine-phosphorylated bacterial proteins. Cell Host Microbe 2009, 5, 397-403. [CrossRef] [PubMed]

64. Sason, H.; Milgrom, M.; Weiss, A.M.; Melamed-Book, N.; Balla, T.; Grinstein, S.; Backert, S.; Rosenshine, I.; Aroeti, B. Enteropathogenic Escherichia coli subverts phosphatidylinositol 4,5-bisphosphate and phosphatidylinositol 3,4,5-trisphosphate upon epithelial cell infection. Mol. Biol. Cell 2009, 20, 544-555. [CrossRef] [PubMed]

65. Backert, S.; Clyne, M. Pathogenesis of Helicobacter pylori infection. Helicobacter. 2011, 16, 19-25. [CrossRef] [PubMed]

66. Edgar, R.C. MUSCLE: Multiple sequence alignment with high accuracy and high throughput. Nucleic Acids Res. 2004, 32, 1792-1797. [CrossRef]

67. Waterhouse, A.M.; Procter, J.B.; Martin, D.M.A.; Clamp, M.; Barton, G.J. Jalview Version 2-A multiple sequence alignment editor and analysis workbench. Bioinformatics 2009, 25, 1189-1191. [CrossRef]

68. Saitou, N.; Nei, M. The neighbor-joining method: A new method for reconstructing phylogenetic trees. Mol. Biol. Evol. 1987, 4, 406-425.

69. Felsenstein, J. Confidence limits on phylogenies: An approach using the bootstrap. Evolution 1985, 39, 783-791. [CrossRef]

70. Jones, D.T.; Taylor, W.R.; Thornton, J.M. The rapid generation of mutation data matrices from protein sequences. Comput. Appl. Biosci. 1992, 8, 275-282. [CrossRef]

71. Kumar, S.; Stecher, G.; Tamura, K. MEGA7: Molecular Evolutionary Genetics Analysis version 7.0 for bigger datasets. Mol. Biol. Evol. 2016, 33, 1870-1874. [CrossRef] [PubMed]

72. Letunic, I.; Bork, P. Interactive tree of life (iTOL) v3: An online tool for the display and annotation of phylogenetic and other trees. Nucleic Acids Res. 2016, 44, W242-W245. [CrossRef] [PubMed]

73. Kumar Pachathundikandi, S.; Brandt, S.; Madassery, J.; Backert, S. Induction of TLR-2 and TLR-5 expression by Helicobacter pylori switches cagPAI-dependent signalling leading to the secretion of IL- 8 and TNF- $\alpha$. PLOS ONE 2011, 6, e19614. [CrossRef] [PubMed]

74. Wiedemann, T.; Hofbaur, S.; Tegtmeyer, N.; Huber, S.; Sewald, N.; Wessler, S.; Backert, S.; Rieder, G. Helicobacter pylori CagL dependent induction of gastrin expression via a novel $\alpha \mathrm{v} \beta 5$-integrin-integrin linked kinase signalling complex. Gut 2012, 61, 986-996. [CrossRef] [PubMed] 
75. Conradi, J.; Tegtmeyer, N.; Woźna, M.; Wissbrock, M.; Michalek, C.; Gagell, C.; Cover, T.L.; Frank, R.; Sewald, N.; Backert, S. An RGD helper sequence in CagL of Helicobacter pylori assists in interactions with integrins and injection of CagA. Front. Cell. Infect. Microbiol. 2012, 2, 70. [CrossRef] [PubMed]

76. Hirsch, C.; Tegtmeyer, N.; Rohde, M.; Rowland, M.; Oyarzabal, O.A.; Backert, S. Live Helicobacter pylori in the root canal of endodontic-infected deciduous teeth. J. Gastroenterol. 2012, 47, 936-940. [CrossRef] [PubMed]

77. Tegtmeyer, N.; Rivas Traverso, F.; Rohde, M.; Oyarzabal, O.A.; Lehn, N.; Schneider-Brachert, W.; Ferrero, R.L.; Fox, J.G.; Berg, D.E.; Backert, S. Electron microscopic, genetic and protein expression analyses of Helicobacter acinonychis strains from a Bengal tiger. PLoS ONE 2013, 8, e71220. [CrossRef] [PubMed]

78. Backert, S.; Dörfel, P.; Lurz, R.; Börner, T. Rolling-circle replication of mitochondrial DNA in the higher plant Chenopodium album (L.). Mol Cell Biol. 1996, 16, 6285-6294. [CrossRef]

79. Backert, S.; Lurz, R.; Oyarzabal, O.A.; Börner, T. High content, size and distribution of single-stranded DNA in the mitochondria of Chenopodium album (L.). Plant. Mol. Biol. 1997, 33, 1037-1050. [CrossRef]

80. Brisslert, M.; Enarsson, K.; Lundin, S.; Karlsson, A.; Kusters, J.G.; Svennerholm, A.M.; Backert, S.; Quiding-Järbrink, M. Helicobacter pylori induce neutrophil transendothelial migration: Role of the bacterial HP-NAP. FEMS Microbiol. Lett. 2005, 249, 95-103. [CrossRef]

81. Brandt, S.; Kwok, T.; Hartig, R.; König, W.; Backert, S. NF-kappaB activation and potentiation of proinflammatory responses by the Helicobacter pylori CagA protein. Proc. Natl. Acad. Sci. USA 2005, 102, 9300-9305. [CrossRef] [PubMed]

82. Moese, S.; Selbach, M.; Zimny-Arndt, U.; Jungblut, P.R.; Meyer, T.F.; Backert, S. Identification of a tyrosine-phosphorylated $35 \mathrm{kDa}$ carboxy-terminal fragment (p35CagA) of the Helicobacter pylori CagA protein in phagocytic cells: Processing or breakage? Proteomics 2001, 1, 618-629. [CrossRef]

83. Hoy, B.; Geppert, T.; Boehm, M.; Reisen, F.; Plattner, P.; Gadermaier, G.; Sewald, N.; Ferreira, F.; Briza, P.; Schneider, G. Distinct roles of secreted HtrA proteases from gram-negative pathogens in cleaving the junctional protein and tumor suppressor E-cadherin. J. Biol. Chem. 2012, 287, 10115-10120. [CrossRef] [PubMed]

84. Moese, S.; Selbach, M.; Kwok, T.; Brinkmann, V.; König, W.; Meyer, T.F.; Backert, S. Helicobacter pylori induces AGS cell motility and elongation via independent signaling pathways. Infect. Immun. 2004, 72, 3646-3649. [CrossRef] [PubMed]

85. Tegtmeyer, N.; Wittelsberger, R.; Hartig, R.; Wessler, S.; Martinez-Quiles, N.; Backert, S. Serine phosphorylation of cortactin controls focal adhesion kinase activity and cell scattering induced by Helicobacter pylori. Cell Host Microbe 2011, 9, 520-531. [CrossRef] [PubMed]

86. Hoy, B.; Löwer, M.; Weydig, C.; Carra, G.; Tegtmeyer, N.; Geppert, T.; Schröder, P.; Sewald, N.; Backert, S.; Schneider, G.; et al. Helicobacter pylori HtrA is a new secreted virulence factor that cleaves E-cadherin to disrupt intercellular adhesion. EMBO Rep. 2010, 11, 798-804. [PubMed]

87. Moese, S.; Selbach, M.; Brinkmann, V.; Karlas, A.; Haimovich, B.; Backert, S.; Meyer, T.F. The Helicobacter pylori CagA protein disrupts matrix adhesion of gastric epithelial cells by dephosphorylation of vinculin. Cell. Microbiol. 2007, 9, 1148-1161. [CrossRef]

88. Tegtmeyer, N.; Hartig, R.; Delahay, R.M.; Rohde, M.; Brandt, S.; Conradi, J.; Takahashi, S.; Smolka, A.J.; Sewald, N.; Backert, S. A small fibronectin-mimicking protein from bacteria induces cell spreading and focal adhesion formation. J. Biol. Chem. 2010, 285, 23515-23526. [CrossRef]

89. Traverso, F.R.; Bohr, U.R.; Oyarzabal, O.A.; Rohde, M.; Clarici, A.; Wex, T.; Kuester, D.; Malfertheiner, P.; Fox, J.G.; Backert, S. Morphologic, genetic, and biochemical characterization of Helicobacter magdeburgensis, a novel species isolated from the intestine of laboratory mice. Helicobacter 2010, 15, 403-415. [CrossRef]

(C) 2019 by the authors. Licensee MDPI, Basel, Switzerland. This article is an open access article distributed under the terms and conditions of the Creative Commons Attribution (CC BY) license (http://creativecommons.org/licenses/by/4.0/). 